\title{
圧力による磁性流体の体皘変化に及ぼす磁場の影響
}

\author{
島田 邦雄访1, 神山 新一出2, 佐藤 彰的3
}

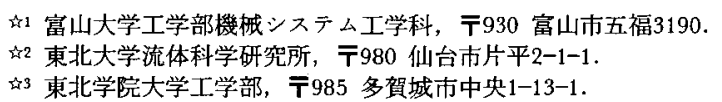

\section{Effect of Magnetic Field on Volume Change of Magnetic Fluid by Pressure}

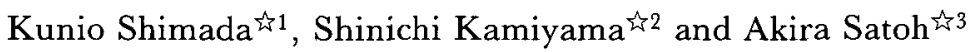 \\ 41 Dept. Mech. Eng. Sys., Toyama University, 3190 Gofuku, Toyama 930. \\ औ2 Inst. Fluid Sci., Tohoku University, 2-1-1 Katahira, Sendai 980. \\ \$3 Dept. Mech. Eng., Tohokugakuin University, 1-13-1 Chuō, Tagajou 985.
}

Received November 26, 1993

The measurement of volumetric change of magnetic fluid influenced by pressure is experimentally conducted. Positive or negative pressure is applied to the magnetic fluid in a nonuniform magnetic field. The experimental results are compared with the data in the case of water. It is clarified that the volume change of magnetic fluid is strongly influenced by the applied pressure and also the applied magnetic field.

\section{1 緒言}

磁性流体は, 直径約 $10 \mathrm{~nm}$ の強磁性微粒子が 液中に多量に分散したコロイド溶液であり，ま た，微粒子には表面活性剂が被覆されている. これらの微粒子は, 磁場の作用域において凝集 することが確認されており ${ }^{1)}$ ，また，無磁場下 においても凝集するということも報告されてい $ろ^{2)}$. 著者らは，この粒子の凝集が磁性流体 の管内非定常流動特性に及ぼす影響について一 連の研究を行ってきだ)ー6)。これらの研究 を通して，振動流特性を説明するのに非圧縮性 流体を仮定した理論解析では不十分である領域 が存在することを指摘した7)。この結果から 磁性流体には圧力に対して容易に変化するとい う性質が存在し，压力による磁性流体の体積変 化が粒子の凝集と絡んで複雑な椂相を呈するこ 亡が予想される.そこで，この磁性流体の圧力
による体積変化について調べる必要がある。し かしながら，この方面に関する研究は，いま だ十分になされていないのが現状である.

そこで, 本研究では，压力の静的変化に対す る磁性流体の体積変化について実験的に検討を 行った。すなわち，管内に閉じ込めた一定量の 磁性流体に負圧力, 或いは正圧力を印加した時 の磁性流体の体積変化について, 磁場の作用の ある場合と無い場合において調へたた。また，あ る大きさの負圧力，或いは正圧力を繰り返し印 加することにより，磁性流体の体積変化に及ぼ す圧力の影響について実験的検討を行った.

\section{2 実硂方法}

磁性流体の静的な压力変化に対する体積変化 を調べるために図 1 に示す様な実験装置を用い

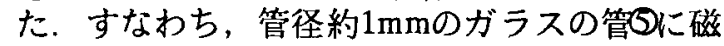
性流体を封入し，これに時間的に静的な压力を 


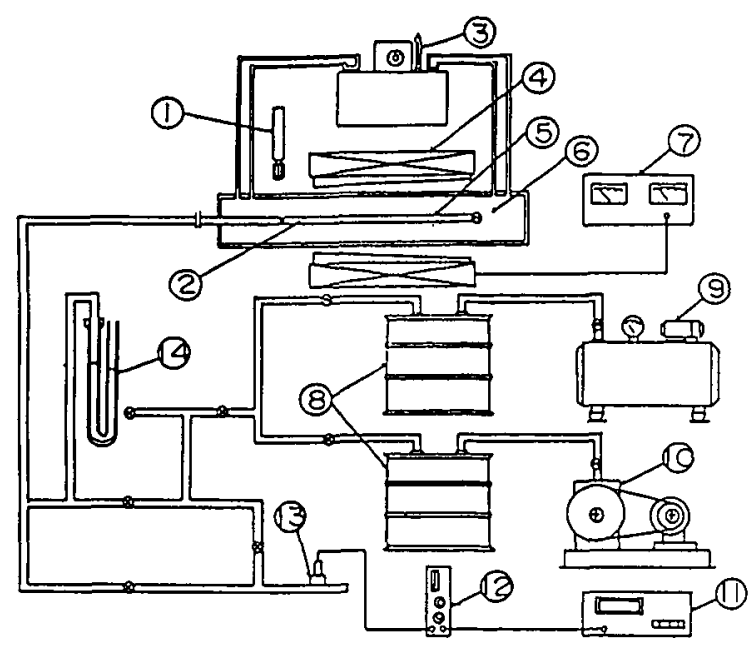

1 Microscope 9 Compressor

2 Magnetic Fluid 10 Vacuum Pomp

3 Heater 11 Voltage Meter

4 Electromagnet 12 D. C. Power Amplifier

5 Circular Tube 13 Pressure Transducer

6 Constant Temperature Vessel

7 Power Supply 14 Manometer

8 Air Tank

Fig.1 Schematic diagram of experimental apparatus.

印加する．このガラス管の先端にはコックがつ いており，コックに空気が残存していないこと は容易に確認でき，この部分における空気の混 入は無いことを確認している，さらに，このコ ックと反対側の管の先端に压力を印加するため のループを組み, 負圧力, 或いは最大䄪 $200 \mathrm{kPa}$ までの正圧力を印加する。 それぞれの圧力は,

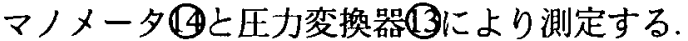
その際, 圧力を印加した時の磁性流体の伸び, 或いは縮みを有尺顕微鏡Qにより測定する。こ こで，磁性流体の先端におけるメニスカスの長 さは，高々1mm以下であり，圧力による磁性流 体の体積変化より小さい。この時，本実験によ り压力に対する磁性流体の体積変化は経時変化 をもつことが確認された。：そこで，压力を印加 した時点から一定の時間経過後に長さを測定し た.

また，測定部のガラス管は，恒温槽Qに入れ 一定の温度に保った．その時の温度変化は高々 \pm 1 Cであり，温度による変化は無視できる．す なわち, 磁性流体の圧力による体積変化は, 等 温変化である，さらに，碰性流体の体積変化に 及ぼす重力の影響について，大気圧下において 磁性流体を封入したガラス管を鉛直に置いた場 合之水平に置いた場合の磁性流体の体積変化を
比較して調べた別実験により，かなり大きいこ とを確認している．そこで本実験では，この重 力の影響を排除するため，ガラス管を水平に配 置した.これらの本実験における磁性流体の圧 力による体積変化の誤差の要因をすべて加味し

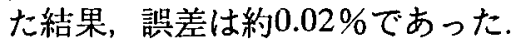

また，磁性流体に作用する磁気压の影響，す なわち，磁場を印加する方向や磁場勾配の大き さにより磁性流体の体積変化が生ずる，本実験 では，あくまで压力に対する磁性流体の体積変 化を目的亡するため，図 2 に示すような磁場分 布を使用する。すなわち，磁性流体に印加する 磁場は，電磁不我に流す供給電流か10A と20Aの 磁場勾配の異なる 2 種類の非一様磁場であり, ガラス管の管軸に対して垂直に印加する。ここ で，図中に示すAの位置が磁性流体の長さの測 定位置であり, Bがコックの位置である.

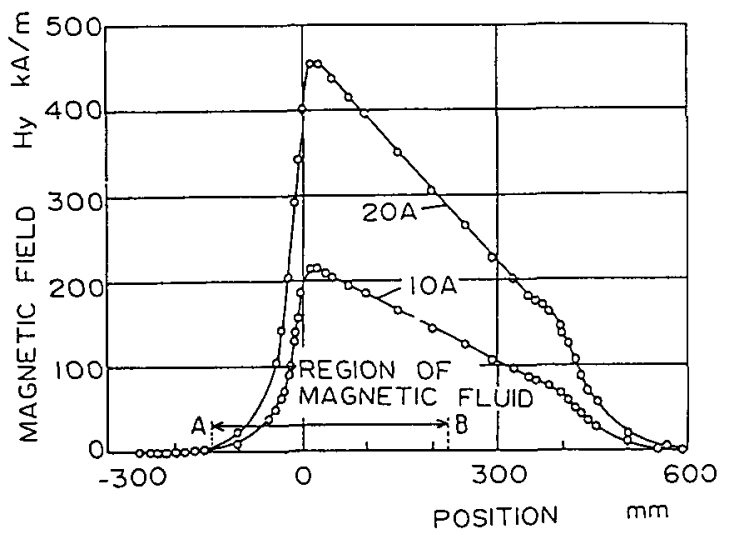

Fig.2 Magnetic field distribution.

使用した磁性流体は，質量濃度約 $20 \%$ の水べ 一ス磁性流体であり，大気压下における磁性流 体の初期の長さは365mmである.

\section{3 実耠結果および考察}

磁性流体の体積変化は，大気圧下における磁 性流体の初期の体積（ $\mathrm{V}_{0}$ ) に対する压力印加 時における体積変化 $(\Delta \mathrm{V})$ の割合で表わすこ とにする。

3. 1 負圧力に対する体積変化

図 3 に負圧力に対する磁性流体の体積変化率 を無磁場下の場合と供給電流が20Aの磁場を印 加した場合について比較して示す．図中の実験 点は，数回の実験による結果であり，また，実 線及び破線は，これらの実験結果を平均した結 果である.

低負圧力の領域において磁性流体の体積変化 率は压力にほぼ比例する。磁場を印加した場合 には体皘変化率が増大する.さらに負压力を大 きくすると，体積変化率はほぼ一定に保たれ， 


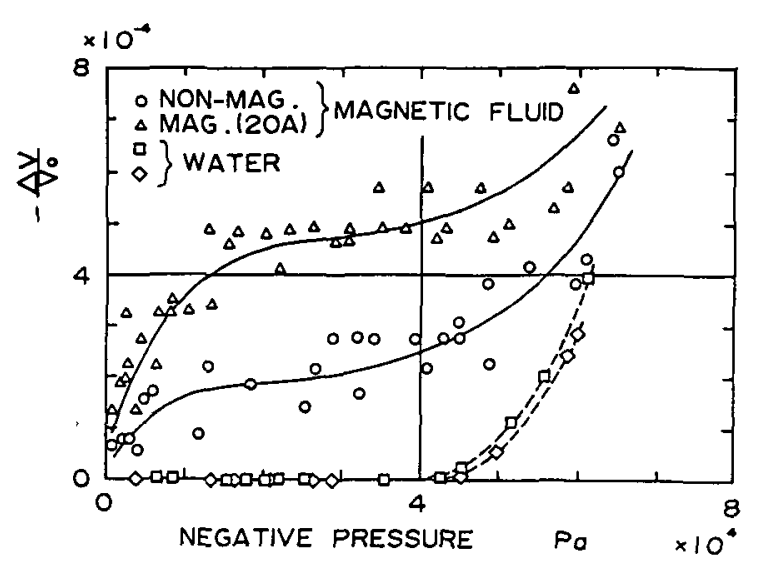

Fig.3 Ratio of volume change by applying negative pressure.

さらに負圧力を増していくと体積変化率は急激 に増大し，その後，ある場合には破断する。こ の破断は，確率的なものであり，管壁の污れや 流体内に存在する不純物なよ゙の影響によるもの である。

ここで，磁性流体の溶媒，すなわち水の場合 には，約 $40 \mathrm{kPa}$ 以下の負压力においては压力に よる体積変化が生じないこと，さらに，本実験 装置のガラス管が压力に対し歪みを生じないこ とは，図に示すように蒸留水を用いて同様の実 験を行って確認してある. 一方，磁性流体之磁 性流体の溶媒（水）について沼知式空気含有量 测定装置により空気の含有率（供試流体の体積 $\left(\mathrm{m}^{3}\right)$ に対する空気含有量 $\left(\mathrm{m}^{3}\right)$ の比) を測 定した結果，本実験で使用した質量濃度 $20 \%$ の 水ベース磁性流体は4.16\%, 原液 34\%の磁性流 体を質量濃度 $20 \%$ の水べース磁性流体に希釈す るために用いた蒸留水は $4.69 \%$ ，通常の水道水 は5.08\%であったここように，磁性流体の空 気含有率が通常の他の流体に較べて小さいのは， 磁性流体中に含まれる空気が微量であるか，ま たは，含有する空気が負圧力を印加しても容易 に外部に出にくいなどのためと考えられる.

そこで以上の結果より，次のように考えるこ 亡が出来る. 低い負圧力を印加した時の磁性流 体の体積変化は，磁性流体中の磁性粒子や表面 活性剂に付着した空気などに起因し，高い負压 力を印加した場合には流体中に含まれる空気の 影響が支配的になるものと考えられる。

3.2 正圧力に対する体積変化

図 4 に正压力に対する磁性流体の体積変化率 を無磁場下の場合と供給電流が20Aの磁場を印 加した場合について比較して示す.

低正压力の領域では，磁性流体の体積変化率 は，負压力の場合と同様に圧力に対してほぼ比 例する．その時の正圧力に対する体積変化率曲 線の傾きは，負圧力の場合に較べて小さい。す

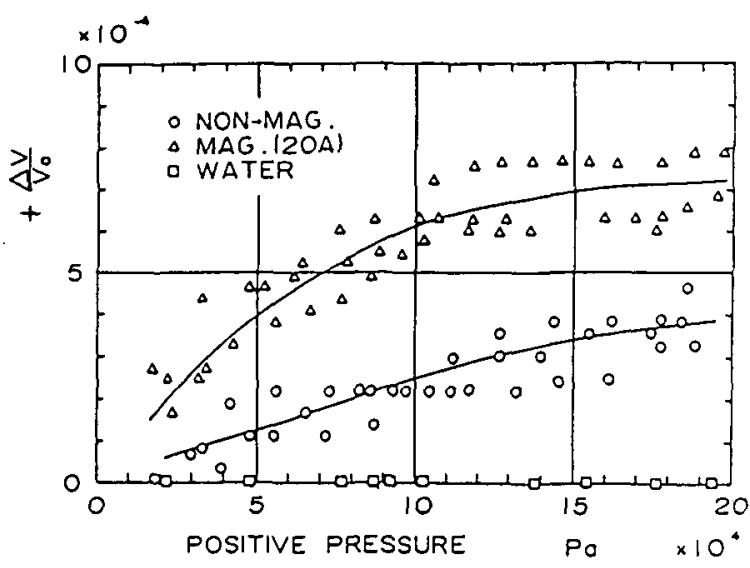

Fig.4 Ratio of volume change by applying positive pressure.

なわち，磁性流体の体皘変化に及ぼす影響は正 圧力より負圧力による方が大きい。この体積変 化は，磁性粒子や表面活性剂に付着した空気な よ゙の影響によるものと考えられる．さらに，正 圧力を大きくすると体積変化率は飽和に達する これは，磁性粒子や表面活性剂に付着した空気 が有限であるためと考えられる.

また，磁場を印加することにより，正圧力に 対する体積変化は大きくなる．この時, 無磁場 下に較べて低い正圧力の大きさで体積変化は飽 和に達する。

3.3 圧力の繰り返し印加による体積変化

磁性流体を用いた非定常流の一つである振動 流の場合には，負压力と正圧力が時間的に繰り 返されて変動圧力として磁性流体に与えられる ことになる．そこで，圧力を繰り返し印加した 時の磁性流体の体積変化について調べるみる. すなわち，負圧力の場合については，約60〜 $80 \mathrm{kPa}$ までの負圧力を掛け，その後圧力を零に 戻し，再び約 60 〜 $80 \mathrm{kPa}$ までの負圧力を掛ける という繰り返しを行い，正圧力の場合について は，約180kPaまでの正圧力を掛け，その後压力 を零に厌し，再び約 $180 \mathrm{kPa}$ までの正圧力を掛け るという繰り返しの実験を行う.

図 5 に供給電流20Aの磁場を印加した負圧力 の場合について示す.

初回の負压力の印加時では，低負压力におい て体積変化率が比例する領域が見られるが，2 回目，3回目亡負压力の印加の回数が増すにつ れて，その領域が消失し，高負厈力による体積 変化率が次第に大きくなる。 また，一度負圧力 を印加した磁性流体は，初期の体積の大きさに まで容易に回復しないが，長時間後にある程度 まで回復する．これは，流体中に存在する空気 が負圧力を印加することにより外部に抜け出る ためと考えられるが，その他に，負圧力を取り 
去った後，磁性流体内部の構造が時間的に流動 して元の状態に回復するものと考えられる.

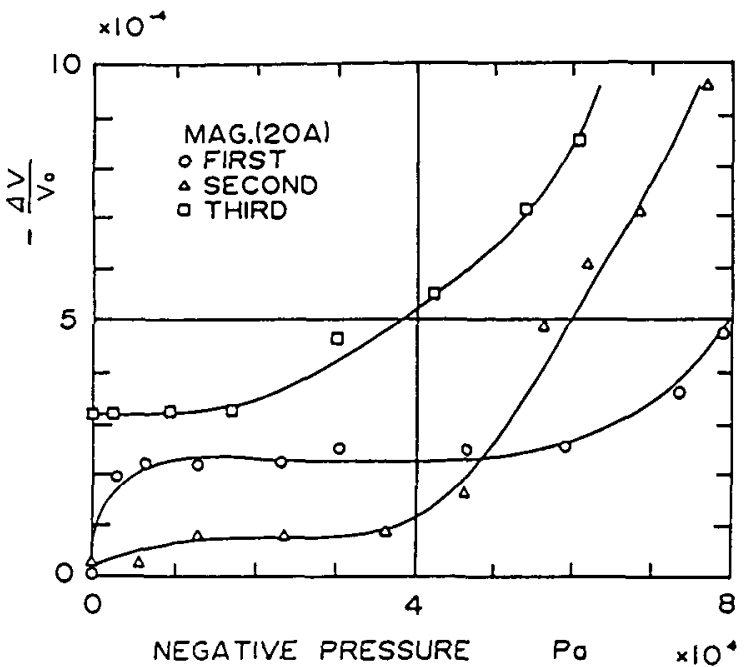

Fig.5 Ratio of volume change by applying negative pressure repeatedly.

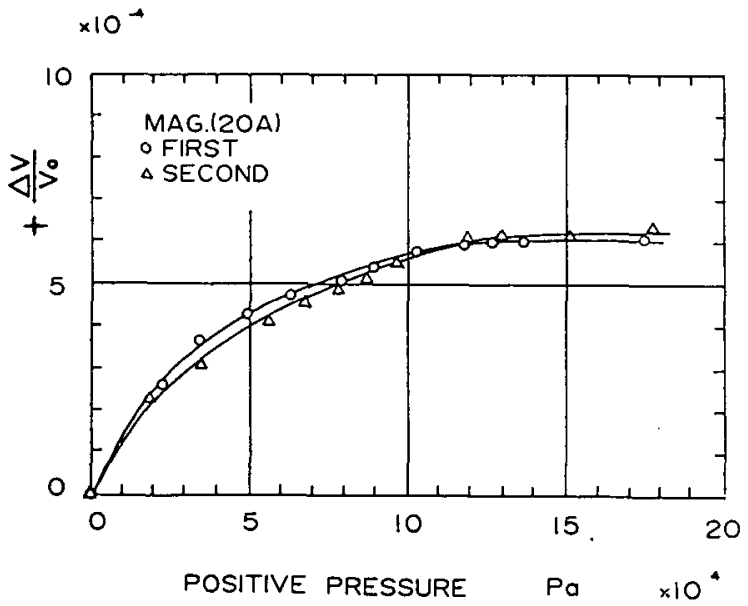

Fig.6 Ratio of volume change by applying positive pressure repeatedly.
次に，供給電流20Aの磁場を印加した正圧力 の場合について図 6 に示す.

この場合には，正圧力に対して幾度でも同じ 量の体積変化率をもつ。すなわち，正圧力の場 合には負压力の場合に較べて，繰り返し圧力に よる磁性流体の体積変化は比較的安定している.

\section{5 結言}

磁性流体に時間的に静的な圧力を印加した場 合の体積変化について実験的に研究を行った。

それにより一般的な特徴が確認された。要約す ると次のようになる。

(1) 磁性流体の負圧力に対する体積変化は, 低压力では体積が比例的に変化し，ある限界压 力を越えると急激に增大するようになる。一方， 正压力を加えた場合にはある值で飽和するよう になる。

（2）磁性流体の圧力に対する体積変化は，磁 場を印加することにより無磁場下の場合に比へ て增大する。

(3) 静的な圧力の繰り返し印加による磁性流 体の体積変化は，負压力の方が正圧力の場合よ りも顕著に表われる。

\section{文献}

1) C. F. Hays: J. Coll. Int. Sci., 52 (1975) 239.

2) A. Satoh, S. Kamiyama: Proc. Conf. Cont. Mec. Appl. Can. Appl. Math. Soc., (1989) 731.

3) K. Shimada, T. Oyama, H. Nishiyama, S. Kamiyama: Int. J. Appl. Electromag. Mat., 2 (1992) 301.

4) K. Shimada, S. Kamiyama: J. Magn. Magn. Mat., 122 (1993) 214.

5) K. Shimada, S. Kamiyama: Proc. 2nd Int. Conf. Fluid Mech., (1993) 776.

6) K. Shimada, S. Kamiyama, A. Satoh: Proc. 3rd World Conf. Exp. Heat Trans. Fluid Mech. Thermo (1993) 1709.

7) 神山新一, 島田邦雄: 日本機械学会論文集, 57-536 В (1991) 1273.

8）沼知福三郎，椎名武：日本機械学会論文集, 3-11 (1937) 177. 